\title{
A vote for the NHS
}

\author{
Fiona Godlee editor in chief, The BMJ
}

Six weeks until the UK general election and the NHS is high on the public's agenda. The parties are busy setting out their stalls, but Nigel Hawkes thinks all the talk of different care models may be just "smoke blown in the face of the electorate to distract attention from the actual state of the NHS" (doi:10. 1136/bmj.h1505).

It'll need to be a thick smog. The NHS's performance has rapidly deteriorated in the past two years, says the health think tank the King's Fund (doi:10.1136/bmj.h1683). Its chief economist, John Appleby, says, “The next government will inherit a health service that has run out of money and is operating at the very edge of its limits."

Meanwhile, the political pledges keep pouring in, uppermost among them better access to primary care. But should we believe promises to recruit up to 8000 extra GPs? Thomas Cowling and colleagues don't think so (doi:10.1136/bmj.h1513). Previous attempts to improve access weren't evaluated, and the new proposals have no clear rationale except to win election votes, they say. Better to focus on properly evaluating new ways of working and investing in public health.

Given the dire financial prognosis, shouldn't the NHS allow clinicians to prescribe cheaper drugs that are equally safe and effective? Yes, say Jeff Aronson and Robin Ferner (doi:10.1136/ bmj.h1723). But life is not that simple. Doctors are being warned not to prescribe generic pregabalin for pain relief even though they can use it for other indications ( $\mathrm{p} 1$ ). And the long running saga of Avastin versus Lucentis has reached new levels of complexity, as Deborah Cohen explains (doi:10.1136/bmj. h1654).

Everyone is holding their breath for the National Institute for Health and Care Excellence to recommend Avastin (bevacizumab) for the treatment of wet age related macular degeneration, with estimated savings to the NHS of $£ 102 \mathrm{~m}$ a year. But, until it does, General Medical Council guidance has left doctors fearful that they will be disciplined for prescribing Avastin off label. Cohen has uncovered attempts by the drugs' manufacturers to scupper publicly funded trials, and she shows how the GMC changed its guidance under pressure from the industry and government, unhelpfully merging "unlicensed" and "off-label" prescribing.

There is a clear double standard here, with Avastin widely used in the private sector. Cohen quotes a public health consultant: "The proposition that it is ethical to provide the cheaper drug to a private individual but unethical when the payer is the public purse is a demonstration of contempt for both the taxpayer and the patients whose care is sacrificed as a result."

We are right to treasure our NHS. Anyone doubting this should read Jennifer Corbelli's personal view (doi:10.1136/bmj.h1517). And in my view we should, as Margaret McCartney asks (doi:10. 1136/bmj.h860), do all we can to set the NHS free from political interference. Henry Marsh agrees (doi:10.1136/bmj.h1483). If he ruled the NHS, he would fund it through a hypothecated tax rather than general taxation, he says. This would stop it being subject to the vagaries of politics and electioneering, he adds, and would force the public to "face up to the fact that healthcare improvement costs money and cannot (as governments are forced to claim at present) be supported by constant improvements in efficiency." I'd vote for that.

For more from The BMJ on the UK general election go to bmj.co/election.

\section{Cite this as: BMJ 2015;350:h1754}

(๑) BMJ Publishing Group Ltd 2015 